\title{
Police gifts and benefits scandals: addressing deficits in policy, leadership and enforcement
}

\author{
Tim Prenzler ${ }^{\ddagger}$, Alan Beckley ${ }^{\dagger}$ and Simon Bronitt ${ }^{\dagger}$ \\ $\ddagger$ (Corresponding author) School of Criminology and Criminal Justice, Griffith University, \\ Mt Gravatt Campus, Brisbane, Queensland, 4122 Australia. Tel: (011-61) (0)7 373 55613; \\ email: t.prenzler@griffith.edu.au \\ †Centre of Excellence in Policing and Security, Griffith University, Brisbane \\ Submitted 23 October 2013; accepted 10 December 2013 \\ Keywords: police ethics, police gratuities, hospitality, gifts and benefits, \\ phone hacking scandal, police corruption
}

International Journal of Police Science and Management, Vol. 15 No. 4, 2013, pp. 294-304 DOI: $10.1350 /$ ijps.2013.15.4.319
Tim Prenzler is a Chief Investigator Australian Research Council Centre of Excellence in Policing and Security

Alan Beckley is an Associate Investigator in the Centre of Excellence in Policing and Security (CEPS) Griffith University;

Simon Bronitt is the Director of CEPS

\begin{abstract}
This paper examines three recent high-profile cases involving gifts and benefits to police. The cases, two from Australia and one from England, involved both frontline officers and senior managers. The analyses track the unfolding scandals, and how they were investigated and evaluated by official inquiries. In two of the cases, gifts and hospitality were enmeshed with wider forms of corruption. The official inquiries identified how gratuities undermined public confidence in the impartiality of police, and how inappropriate gifts and benefits were facilitated by liberal policies and deficient leadership. The paper concludes by arguing that police need to adopt a highly restrictive policy on gratuities, and follow through with effective forms of compliance management.
\end{abstract}

\section{INTRODUCTION}

Gifts and benefits, or 'gratuities', offered to police have attracted considerable attention in the police ethics literature and have been an area of official policy development, mainly through prescriptive statements in codes of conduct. There is a view that minor gifts can be harmless and assist police-community relations by allowing members of the public to express their appreciation directly to police (Kania, 1988). However, some codes of conduct take a complete prohibitionist position. For example, the prominent International Association of Chiefs of Police Law Enforcement Code of Conduct states categorically, 'I will enforce the law courteously and appropriately without fear or favour, malice or ill will, never employing unnecessary force or violence and never accepting gratuities' (2004, p. 45). The rationale for prohibition is that gratuities entail a high risk of loss of public respect and confidence in police. This is due to a perception that the donor will receive or expect favourable treatment. Gifts to police are also often seen as an 
unfair career benefit not available to most workers.

A number of studies have suggested that complete prohibition can create difficulties and have proposed a 'near-zero' policy instead (Prenzler, Beckley, Bronitt, \& Saunders, 2012). At times, police may need to conform to customary practices of giftgiving and hospitality. Examples include gifts, such as an engraved pen or a plaque, given to a police officer after a term in a community service position-such as a school-based police officer. A free meal at a breakfast or dinner presentation to a business or community group would also be acceptable. Another example is that of a police officer accepting a non-alcoholic beverage when interviewing a victim of crime (Coleman, 2004, p. 42):

Imagine an officer who goes to the home of a victim of violent crime in order to get a statement from the victim. The victim is badly shaken, and asks the officer to have a cup of tea with her while making the statement. The 'no gratuities' code will mean that the officer must refuse the cup of tea, which is likely to put the victim offside straight away.

Police might also justifiably accept free food and drink during policing operations or civil emergencies when a normal selffunded refreshment break is difficult.

With these examples in mind, a number of strict conditions would need to apply to permissible gratuities. The gift or hospitality should only be accepted in circumstances where there is no likelihood of a real or apparent conflict of interest. The gift should be of very minor value and not occur where a normal commercial transaction would be expected. Recurring gratuities should be prohibited, such as standing discounts from fast food outlets; and soliciting gratuities should be prohibited

Tolerance of minor and incidental gratuities receives support from public opinion.
A US survey found that 59 per cent of respondents agreed with the statement, 'it is appropriate for a police officer to accept an occasional free coffee, non-alcoholic drink, or discounted meal when on-duty' (Jones, 1997, p. 9). An Australian survey found 66 per cent of respondents expressed support for the same scenario, while 17 per cent supported and 76 per cent opposed 'regular free coffee, cold drinks or discounted meals when on duty' (Prenzler \& Mackay, 1995, p. 22). In the same study, the majority of respondents (95-97 per cent) were against gifts such as free meals while off duty. The main reasons cited for the minimalist view in both instances was that a gift 'creates the expectation that a favour or service will follow' (59 per cent) and 'makes the police officer look like he or she is corruptible' (48 per cent) (p. 23).

Research and inquiries have also identified negative outcomes from police gratuities. There is some evidence that acceptance of discounted food affects the visibility of police in favour of locations that provide gratuities (DeLeon-Granados \& Wells, 1998; Ruiz \& Bono, 2004). A survey of police officers found that 57 per cent said they would overlook a serious traffic offence committed by a person who had provided gratuities (Macintyre \& Prenzler, 1999, p. 194). Inquiries like the famous Knapp Commission in New York found that police frequently wasted time enjoying free drinks in bars instead of patrolling and investigating crime (1972, p. 146). Knapp and other inquiries have found police harassed proprietors who did not offer discounts (see also Wood, 1997). While gratuities are often small, the financial value can quickly accumulate into large sums, and pursuing discounts can become a preoccupation for some officers (Kania, 1988; Ruiz \& Bono, 2004).

Available evidence also suggests that gratuities are an area where there is often a large gap between policy and practice. 
While codes usually prohibit officers accepting most gifts; in reality, police acceptance of gratuities is commonplace, most noticeably through fast food outlets. The situation is consistent with the 'two cultures' thesis of policing (Reuss-Ianni, 1983). Police managers make strong rhetorical statements against gratuities but have little interest in compliance management or are concerned about a backlash from frontline officers and unions if they attempt to enforce policy.

The acceptance of gratuities appears to be a feature of policing in many jurisdictions. While they do not attract the same outrage as graft and assaults, gratuities do still constitute 'a police image problem that doesn't seem to go away' (Benson \& Skinner, 1988, p. 32). With this alleged problem in mind, the following three case studies examine how gratuities have generated controversy and adverse publicity for police. The analysis of media and public reactions in these cases, and the findings of official inquiries, provide useful lessons for improved practice.

\section{CASE STUDY 1: 'BEVERLY HILLS COP'}

Christine Nixon was the high-profile Chief Commissioner of Police in Victoria, Australia, from 2001 to 2009. In October 2008, Nixon and her husband travelled first class as guests of Qantas on the inaugural A380 Airbus flight from Melbourne to Los Angeles, staying a night at the Sofitel in Beverley Hills and attending two functions. Her participation in the luxury flight quickly came under attack in the media. Nixon was described as returning to 'a firestorm' of controversy. Over a 12-month period, the four-day trip attracted 76 references in the Australian print media; almost all of them negative, including critical editorial comments and letters to the editor (www. global.factiva.com, accessed 14 July
2013). Dubbed 'the Beverly Hills Cop Affair', the trip was considered 'naïve' at best and, more pejoratively, as a 'freebie' and 'junket'. The Police Association called for Nixon's resignation, arguing that ordinary officers would have been disciplined in the same situation. The revelations fuelled calls for the introduction of an anti-corruption commission to deal with similar cases involving senior public officials.

In response, the Chief Commissioner issued a press release stating the trip was a gift to her husband, a former Qantas employee, and that she had taken leave and accompanied him as his partner (OPI, 2009 , p. 8). A complaint was then made to the Office of Police Integrity (OPI) alleging the statement misrepresented the facts and that the trip was in breach of a prohibition on gifts of 'more than token value' (OPI, 2009, p. 7).

The Director of the OPI, Michael Strong, launched an investigation and published the findings in a report Offers of Gifts and Benefits to Victoria Police Employees. The OPI found there was evidence that the purpose of the airline's invitation was to capitalise on Nixon's profile as 'a very popular Chief Commissioner' (OPI, 2009, p. 10). Nixon testified that she and her husband had first received a verbal invitation and that this, along with her husband's previous employment with Qantas, was the basis for her view that the invitation was to her husband. However, the OPI noted that Nixon received a formal letter of invitation as Chief Commissioner, that her staff made arrangements, and that she participated in a promotional group photo shoot and made positive public comments about the flight. The value of the trip to Nixon alone was placed at more than $\$ A U 20,000$.

The OPI Director found that the Chief Commissioner had breached the code, primarily in relation to acceptance of gifts above token value. Strong conciliated the complaint, and it was agreed that Nixon 
would make a statement accepting that her actions were in breach of the code. The statement was published in the Police Gazette and internal police communications. Nixon expressed regret over the trip and conceded that she had been under a misapprehension regarding Qantas's view of her role. She also conceded that 'my conduct has not provided a good example for Victoria Police members to whom gifts and benefits may be offered' (in OPI, 2009, p. 19). She also offered to repay the costs of the trip. However, Qantas refused the offer and she made a donation of $\$ A U 5,000$ to charity.

The OPI report included a final chapter, 'Policy and Practice Reform'. Strong found the existing policy was not enforced, and both education and leadership on the issue had been deficient. He emphasised the policy should explicitly prioritise public over private interests and reduce acceptable gifts to the absolute minimum, leaving space only for 'token gifts of appreciation ... such as a book voucher for giving a talk or presentation at a community group' (OPI, 2009, p. 14).

The report also noted that in December 2008 the Victoria Police Ethical Standing Committee had launched a review of the issue, and Strong sought to delay his report in order to critique the revised policy. However, the OPI report was published in June 2009 without a new policy being finalised and with Strong expressing frustration over the delay. He noted that he was aware of 'other examples of senior police accepting benefits in the form of free tickets to the races, sporting events, musical festivals and the like' (OPI, 2009, p. 5). The new Chief Commissioner, Simon Overland, cited a preference to see through a cross-government review. In the interim, in October 2010, the OPI published a report, Managing Conflict of Interest in Victoria Police, which included case studies from recent investigations and concluded that senior police were still not demonstrating leadership, and not communicating and enforcing appropriate standards (OPI, 2010).

In 2010, the Victorian State Services Authority reported on a new sector-wide policy. The Gifts, Benefits and Hospitality Policy Framework provides a non-mandatory guide for heads of departments to promote ethical practice. The framework includes minimum standards for ensuring integrity and impartiality in government, along with exemplar responses to scenarios (State Services Authority, 2012)-entailing an approach largely consistent with the "nearzero' policy outlined above. The Framework notes that 'many organisations may find that a total ban on gifts and hospitality is impractical or unrealistic', and that there may be community benefits from public servants accepting some hospitality-'light refreshments' for example - and 'tokens, mementos and small gifts of appreciation' (p. 11). Personal acceptance of gifts of more than 'nominal value' and 'repeat gifts' is prohibited (p. 13). 'Nominal value' is defined as up to $\$ A U 150$ (p. 5).

These guidelines do not, however, appear to have been adopted by the police, and there have been no follow-up reports on implementation by the OPI, possibly because of the transition to a new publicsector wide anti-corruption commission. The lack of action by Chief Commissioner Overland is not surprising given his forced resignation in 2011 in a scandal involving multiple accusations of wrongdoing. The Victorian Ombudsman (2012) reported, amongst other things, that Overland accepted a number of gifts in breach of the code. These included free attendance at expensive sporting functions and luncheons, and membership of the Melbourne Cricket Club (paid by Overland but with a membership waiting list of more than 217,000). Overland defended these as essential to corporate public relations. 
The current Victoria Police Code of Conduct, available online and published in February 2010, contains a statement, consistent with one of the OPI's 2009 recommendations, that 'all conflicts of interest must be resolved in favour of the public interest' (Victoria Police, 2010, p. 7). However, there is no clear policy on gifts and benefits. Readers are instead referred to a section of the Victoria Police Manual, 'Managing Conflict of Interest', which is not available online.

\section{CASE STUDY 2: OPERATION TESCO}

In June 2011, the police oversight body in the Australian state of Queensland, the Crime and Misconduct Commission (CMC), released Operation Tesco: Report of an Investigation into Allegations of Police Misconduct on the Gold Coast. Tesco was triggered by mounting evidence of misconduct that could not be ignored. The operation employed a variety of investigative techniques including telephone intercepts, covert surveillance, and closed and open hearings. Tesco produced two types of findings. Six officers were identified, including a sergeant and an inspector, who were engaged in criminal conduct or clear breaches of duty. Two officers were involved in serious offences, including assault, protecting offenders, accessing and communicating confidential information, illicit drug use, falsification of evidence, misuse of police property, and persecution of a whistleblower. A third officer was found to have regularly feigned illness to take sick leave while operating a coffee van business.

The second area of findings concerned a wider set of questionable practices and deficiencies in organisational culture and leadership. The practices included nonreporting of misconduct, improper associations with criminals, and a culture of rowdy off-duty binge drinking fuelled by free alcohol. Excessive alcohol consumption was facilitated by the use of 'blue light taxis' or 'BLTs'-colloquialisms that described transport home for intoxicated police from licensed establishments in police vehicles driven by officers on duty. In a $3 \frac{1}{2}$ month period, investigators identified 24 officers involved in giving or receiving lifts, and 29 of 30 officers questioned on the matter admitted they had made use of the service at least once. Officers testified that the use of police vehicles as 'private taxis' was encouraged by senior police, ostensibly to prevent drunk driving by officers. There was also a culture of illicit steroid use amongst a smaller group of officers. However, officers from all over the state were found to have attended the offices of a doctor who admitted supplying steroids to police.

The Tesco Report included a section, 'Receipt of free or discounted alcohol, food and hospitality' (CMC, 2011, p. 14). Investigators found it was common practice for police to visit licensed premises when offduty, where they received free entry and free drinks. Some premises provided drink cards with values of $\$ A U 50$ and $\$ A U 100$ :

About 20 police officers examined in the CMC closed hearings stated that they had received free drinks. One officer testified that over a nine-month period he received approximately 18 drink cards with a total value nearing $\$ 1800 \ldots$ Many of nearly 50 police officers who were questioned admitted that they rarely, if ever, paid the normal $\$ 10$ to $\$ 20$ cover charge to gain access to a nightclub or licensed venue (p. 14).

Testimony from police and nightclub owners indicated that free entry and drinks were provided to enhance security.

As part of its investigation, the CMC considered the arguments for and against police gratuities, including discounts from fast food outlets. The Commission also conducted a public opinion survey, which 
found that 61 per cent of respondents were opposed to regular gratuities, while 66 per cent supported an occasional minor gratuity and 84 per cent opposed any gifts of alcohol (p. 30). The report concluded that a stricter policy on gratuities was required to improve the public image of police and reduce risks of favouritism and improper associations. It was argued that businesses that attract police with free or discounted merchandise are, 'in essence, purchasing preferential treatment. Businesses who cannot afford to provide police with gratuities are likely to receive less of a police presence in or near their premises' (p. 29).

Overall, the CMC found there had been a long-standing problem in Gold Coast policing, marked by 'a general erosion of standards of conduct ... and a failure to recognise the seriousness of misconduct or inappropriate conduct' (p. 1). The revelations received widespread adverse press coverage, including references to a 'culture of freebies' (http://www.global.factiva. com, accessed 17 July 2013). During the investigation, the Police Commissioner initiated a reform programme, approved by the CMC, including revised procedures, training and supervision, and a review of the gifts and benefits policy (p. 31).

In December 2011, the Police Commissioner issued a press release stating that a new policy on gifts and benefits would take effect from January 2012:

The policy specifically addresses the key issue arising from Operation Tesco by prohibiting free or discounted entry to licensed premises and the acceptance of free or discounted alcohol, where membership of the Service is the determining factor in the offer and acceptance of the gifts or benefits can reasonably be perceived as a conflict of interest (Queensland Police Service, 2011a, p. 1).

Acceptance of 'recurring offers of discounted goods/services' was described as 'inconsistent with the values of the QPS'. On the issue of enforcement, the statement made a commitment to a disciplinary response to breaches of the alcohol policy. A 'cultural change approach' was adopted in relation to regular discounts, recognising these were 'accepted practice' (p. 1). The Commissioner called for 'the support of all police officers and particularly supervisors in terms of discouraging the acceptance of such benefits, through educational and managerial strategies' (p. 1).

The police union General Secretary described the policy as 'unenforceable ... unjust, discriminatory and unnecessary', alleging 'every person these days is offered some form of discount' (Leavers, 2011, p. 2). The media gave the announcement positive coverage, with headlines such as 'No more free lunches for our police officers' and 'Queensland Police banned from free burgers, doughnuts' (http:// www.global.factiva.com, accessed 14 July 2013). Despite all this, the official code of conduct at the Police Service website, dated January 2011, is vague on the issue of gifts and benefits, with readers referred to an offline document for details (Queensland Police Service, 2011b, p. 15).

\section{CASE STUDY 3: CORPORATE PUBLIC RELATIONS AND THE PHONE HACKING SCANDAL}

In the UK, the 'News International Phone Hacking Scandal' included allegations of gifts and benefits from newspapers to police and improper influence. The scandal erupted in July 2011 when an investigative report in The Guardian alleged that the tabloid News of the World had accessed the mobile phone of a 13 year-old girl who had disappeared. An inquiry by Justice Brian Leveson was established in the same month. A series of other investigations and reviews was also launched. As of July 2013, Operation Elveden, an investigation of possible 
bribery of police and other public officials by journalists, had resulted in 64 arrests (Home Affairs Committee, 2013, p. 21).

The core allegation in the scandal was that the News of the World and other tabloid newspapers solicited information from private investigators and other parties who accessed the phone messages and emails of hundreds of persons of interest to the media. In that regard, there have been numerous resignations, admissions and arrests related to breaches of telecommunications privacy laws. The scandal also extended out through concentric rings of illegal and unethical practices. A key area of inquiry concerned inappropriate relations and undue influence involving the press and police. The Commissioner of the Metropolitan Police Service (MPS), Sir Paul Stephenson, resigned in July 2011 over the scandal. He was followed by Assistant Commissioner John Yates, who took responsibility for the failure of the MPS to investigate a trove of evidence about phone hacking.

The Leveson Inquiry report was published in November 2012. Leveson concluded that the failure of police to properly investigate allegations of phone hacking and stop the practice of illicit informationgathering by the press resulted in part from close and inappropriate relationships between the two groups, which were facilitated by a number of factors including gifts and hospitality. The report also noted that close relationships fuelled perceptions of favouritism even where no evidence existed. For example, the report noted that a key factor in Stephenson's resignation was the disclosure of a five-week stay free of charge at a Champneys' luxury rehabilitation resort. Stephenson was unaware of vague business connections between the resort and the press, but this figured in media coverage. A 2013 report on Leadership and Standards in the Police by the House of Commons Home Affairs Committee noted specifically in relation to Stephenson's stay at the resort (valued at $\mathcal{K}^{12,000)}$ that:

It should not be acceptable that officers of any rank should receive free treatment in a private hospital or convalescent home where payment would otherwise expect to be made by the individual. There are bound to be questions asked why such free provisions have been provided, and all the more so if the officers concerned are of senior rank. (2013, p. 26)

The Leveson Report also documented the intensity of Stephenson's acceptance of hospitality and meetings with media figures with the following example from 2009:

He met with the editor of the Sunday Telegraph on 19 February; he had drinks with the editor of the Daily Telegraph on 10 March; he met with the Mirror Group on 18 March and with the editorin-chief of the Daily Mail on 24 March. On 20 April, he had lunch with the editor of The Sun ... and on 28 April with MrWitherow of The Sunday Times. There was a business dinner with $\mathrm{Mr}$ Myler, editor of the NoTW, on 14 May and a News Corporation reception at OXO Tower on 17 June. On 27 June there was a meeting with Richard Littlejohn and Stephen Wright of the Daily Mail. The rest of the year followed a similar pattern. (Leveson, 2012, pp. 921-922)

These kinds of meetings were defended by police as essential public relations activities (pp. 920-922).

The Leveson Inquiry drew on and supported the findings of other inquiries and reviews. The Filkin Review was initiated by Commissioner Stephenson to inquire into the relationship between the media and the 
MPS. Among other things, Filkin identified a double standard and a pattern of 'excessive hospitality' enjoyed by senior police (2012, p. 19). In testimony before Leveson, Filkin referred to lunches and dinners 'at rather expensive restaurants' and 'very large numbers of tickets to very expensive sporting events' (Leveson, p. 962). Filkin also reported that the gifts and hospitality were widely viewed as corruption by many members of the MPS.

At the instigation of the Home Secretary, Her Majesty's Inspectorate of Constabulary conducted a review Without Fear or Favour: A Review of Police Relationships. The review concluded that policies on gifts and benefits were unclear and largely unenforced, and that a more restrictive and nationally consistent approach was needed (HMIC, 2011). The Association of Chief Police Officers (ACPO) was tasked with implementing the recommendations, and Leveson was largely supportive of new guidelines (2012, p. 989). The ACPO Guidelines on Gifts, Gratuities and Hospitality appear to restrict allowable gratuities to very minor benefits. 'Regular free or discounted food or refreshments' are explicitly prohibited (2012, p. 6). Subject to qualifiers about public perceptions, permitted items include 'light refreshments' or 'a conventional meal' at community events, conferences or with other policing agencies (2012, pp. 6 \& 4).

Also at the instigation of the Home Secretary, the Independent Police Complaints Commission (IPCC) conducted research on the nature and extent of police corruption. A preliminary report focused on the Commission's work in relation to serious criminal matters (IPCC, 2011). The report did note, however, that saturation media coverage of non-criminal police conduct issues contributed to public perceptions of widespread abuses and exploitation of police authority (p. 16). Although elements of the media were instrumental in instigating police misconduct in the phonehacking scandal, the media were also instrumental in exposing and condemning misconduct. The second IPCC report included public opinion research. The survey found that 44 per cent of respondents had heard something about police corruption in the three months of peak coverage of the scandal, and that 98 per cent of this group had obtained information from the media (IPCC, 2012, pp. 15-16). Respondents were also given scenarios about possible types of police misconduct. Three scenarios involved gifts and benefits. Regular free food and drink from a cafe was considered 'definitely corruption' by 26 per cent and 'probably corruption' by 30 per cent (56 per cent in total) (p. 17). Free entry to a nightclub off duty scored 25 per cent and 28 per cent respectively ( 53 per cent). A free lunch at an external meeting scored 9 per cent and 14 per cent (23 per cent).

A speech on police integrity, given by the Home Secretary in Parliament in February 2013, represented something of an official conclusion to the phone-hacking scandal and several other policing scandals. May announced a package of anticorruption initiatives, including an enlarged role for the IPCC, a chief officers' gifts and hospitality register published online, and a common code of ethics to be developed by the new College of Policing. There was a promise that officers would be 'trained and tested' on the new standards 'throughout their careers' (May, 2013, p. 2).

\section{DISCUSSION}

The three case studies analysed above all involved different jurisdictions and circumstances but a very similar set of findings. Gifts and benefits to police do not constitute a trivial issue that can be easily ignored. Acceptance of anything other than 
very minor gifts and customary hospitality on an incidental basis is at odds with democratic policing and public expectations. Furthermore, regardless of one's view on the ethics of gratuities, they can function as a 'sleeper issue', likely to erupt-especially in combination with other problems-and cause a scandal with far-reaching consequences. The costs include diminution of public trust and, to add insult to injury, the considerable burden on the taxpayer of official inquiries and reviews.

Another feature of the case studies is how they show the failure of police leaders to learn from experience. In the Victorian case, it was pointed out in the press that police gratuities had generated controversy in the past, including a major scandal over free flights. In the Queensland case, there were at least two decades of negative media over half-priced hamburgers and corporate gifts to senior officers. The CMC inquiry also found that an investigation 10 years earlier had identified:

procedural and managerial deficiencies, some of which foreshadowed the issues that arose in Operation Tesco such as inappropriate associations between police and Gold Coast nightclub owners and staff; the receipt by police officers of free drinks in nightclubs; and preferential treatment shown by police officers towards those establishments, including the lack of enforcement of serious crimes involving them, such as drug use and distribution. (2011, p. 4)

In the UK, the HMIC review observed that the issue of gifts and benefits had been examined in detail in a report over 10 years previously and that the recommendations were largely ignored. The earlier report, Police Integrity: Securing and Maintaining Public Confidence, found that what counted as allowable gifts was 'left open to wide interpretation', chief constables were unaware of the extent of the problem, and gratuities alienated the public (1999, p. 43). The report recommended a significant tightening of policy, national standardisation, and a key role for chief constables in communicating and modelling standards. The 2011 HMIC review also found an ongoing problem with an 'it would not happen here' mindset amongst police leaders outside London (2011, p. 10).

This makes for a pessimistic scenario concerning the likelihood of real and lasting improvements. It is generally recognised that reform agendas will fail without committed leadership (Beckley, 2012). In the Victorian case, it appears that the apparent determination of the police oversight body the OPI to see the issue through dissipated with the departure of the Director and creation of a new Independent Broad-based Anti-corruption Commission in 2012. In Queensland, the issue appears to have fallen off the CMC's agenda. The Police Service made a public commitment to a 'cultural change' initiative, but there is currently no impact assessment available. In the UK, it is still early days, with the ACPO Guidelines approved in October 2012. Given the relative autonomy of UK police forces, it is likely that acceptance of the guidelines and any compliance or enforcement activity will be uneven and very much subject to the personal commitment of chief constables. The most likely cause for optimism regarding implementation comes from the array of bodies-such as ACPO, HMIC, the IPCC and the new College of Policingwhich might provide ongoing scrutiny and pressure (Home Affairs Committee, 2013). There are also sufficient documented examples available in the policing literature of good practice and sustained improvements-in complaint reduction for example - to make it possible to conceive 
of a successful change management process in relation to gratuities (Prenzler, 2012).

\section{CONCLUSION}

The three case studies examined in this paper show how small things matter when it comes to police probity, legitimacy and public confidence. The practice of police accepting meals, hospitality and other benefits is increasingly unacceptable in many locations. Arguments about corporate public relations, used to justify larger gifts to top police, are also rightly viewed with scepticism. Recent scandals, documented in these case studies, demonstrate the need for change. Codes of conduct should be clearly aligned with a position of 'near-zero' tolerance. Police leaders need to take actionboth in setting an example and establishing an effective compliance management programme. Without decisive action and ongoing vigilance, gratuities will continue to be 'a police image problem that doesn't seem to go away' (Benson \& Skinner, 1988, p. 32).

\section{References}

ACPO (2012). ACPO Guidelines on gifts, gratuities and hospitality. London: Association of Chief Police Officers.

Beckley, A. (2012). Capacity building to foster anti-corruption in policing organizations. In DCAF toolkit on police integrity. Geneva: Center for Democratic Control of Armed Forces.

Benson, B. L., \& Skinner, G. H. (1988). Doughnut shop ethics: There are answers. The Police Chief, December, 32-33.

CMC (2011). Operation Tesco: Report of an investigation into allegations of police misconduct on the Gold Coast. Brisbane: Crime and Misconduct Commission.

Coleman, S. (2004). When police should say 'No!' to gratuities. Criminal Justice Ethics, 23(1), 33-43.
DeLeon-Granados, W., \& Wells, W. (1998). 'Do you want extra police coverage with those fries?' Police Quarterly, 1(2), 71-85.

Filkin, E. (2012). Ethical issues arising from the relationship between police and the media. London: Metropolitan Police Service.

HMIC (1999). Police integrity: Securing and maintaining public confidence. London: Her Majesty's Inspectorate of Constabulary.

HMIC (2011). Without fear or favour: A review of police relationships. London: Her Majesty's Inspectorate of Constabulary.

Home Affairs Committee (2013). Leadership and standards in the police, Volume I. London: House of Commons.

International Association of Chiefs of Police (2004). Law enforcement code of conduct. In Police Chiefs Desk Reference. Washington, DC.

IPCC (2011). Corruption in the Police Service in England and Wales: Part 1. London: Independent Police Complaints Commission.

IPCC (2012). Corruption in the Police Service in England and Wales: Second Report. London: Independent Police Complaints Commission.

Jones, M. (1997). Police officer gratuities and public opinion. Police Forum, October, 8-11.

Kania, R. (1988). Should we tell the police to say 'yes' to gratuities? Criminal Justice Ethics, 7(2), 37-49.

Knapp, W. (1972). Report of a Commission to Investigate Allegations of Police Corruption and the City's Anti-corruption Procedures. New York: City of New York.

Leavers, I. (2011). General President's message. Queensland Police Union Journal, April, 2.

Leveson, B. (2012). An inquiry into the culture, practices and ethics of the press, Volume II. London: The Stationery Office.

Macintyre, S., \& Prenzler, T. (1999). The influence of gratuities and personal relationships on police use of discretion. Policing and Society, 9, 181-201.

May, T. (2013, February 12). Speech by the Home Secretary on police integrity. Retrieved July 17, 2013 from https://www. 
gov.uk/government/speeches/speech-bythe-home-secretary-on-police-integrity.

OPI (2009). Offers of gifts and benefits to Victoria Police employees. Melbourne: Office of Police Integrity.

OPI (2010). Managing conflict of interest in the Victoria Police. Melbourne: Office of Police Integrity.

Prenzler, T. \& Mackay, P. (1995). Police gratuities: What the public think. Criminal Justice Ethics, 14(1), pp. 15-25.

Prenzler, T., Beckley, A., Bronitt, S., \& Saunders, J. (2012). Rethinking police gifts and benefits policies. Brisbane: Centre of Excellence in Policing and Security, Griffith University.

Prenzler, T. (Ed.) (2012). Policing and security in practice: Challenges and achievements.

Basingstoke: Palgrave-Macmillan.

Queensland Police Service (2011a). New gifts and benefits policy. Retrieved July 14, 2013, from http://mypolice.qld.gov.au/blog/ 2011/12/29/new-gifts-and-benefits-policy/

Queensland Police Service (2011b). Standard of practice. Retrieved July 14, 2013, from http: //www.police.qld.gov.au/Resources/
Internet/services/reportsPublications/ documents/QPSStandardofPractice.pdf

Reuss-Ianni, E. (1983). Two cultures of policing. New Brunswick, NJ: Transaction Books.

Ruiz, J., \& Bono, C. (2004). At what price a 'freebie'? The real cost of police gratuities. Criminal Justice Ethics, 23(1), pp. 44-54.

State Services Authority (2012). Gifts, benefits and hospitality policy framework. Retrieved January 10, 2014, from http://www.ssa. vic.gov.au/images/stories/product_files/ 670_GBHF_revised_2012.pdf

Victorian Ombudsman (2012). Investigation into allegations of improper conduct involving Victoria Police. Retrieved January 10, 2014 from https://www.omsbudman.vic.gov.au/ getattachment/57336545-d4af-4976-a047$661 \mathrm{~cd} 3260303 /$ reports-publications/ parliamentary-reports/investigation-intoallegations-of-improper-con-(1).aspx

Victoria Police (2010). Code of conduct. Retrieved July 13, 2013, from http:// www.police.vic.gov.au/content.asp? Document_ID=30299.

Wood, J. (1997). Royal Commission into the New South Wales Police Service: Final report. Sydney: NSW Government Printer. 